\title{
Iets oor die ware in die Kuns
}

Nie om die uitgetrapte vraagstuk omtrent die waarheid, veral soos in die waardefilosofie gefigureer het, is dit my te doen nie; alleen mar om enkele gedagtes rakende die verhouding van die kunstenaar tot sy werk op hierdie stuk.

Waarhede is talryk waar die bo-sinlike struktuuridee of wetsorde geaktualiseer word aan en in die individuele figuur soos bv. die kunswerk wat eers op dié wyse moontlik word en nie alleen onderworpe is aan die estetiese norm nie, maar ook 'n weerspieëling is van alle aspekte van die werklikheid in analogiese $\sin$. Want om die kuns vry te verklaar van ander norme, dus te verabsoluteer (die kuns om die kuns), bly en is sidar net teoretiese gepraat, omdat die kunswerk in die sinsamehang van die werklikheid en in die tyd eers tot stand kom, terwyl al die tydelike warhede uitwys na die Absolute Waarheid wat God is. Daarom was ook van 'n ander kant uit alle biologistiese of psigologistiese oorheersing (Waetzoldt, Freud) ydel en verspot as teoretiese verbreking van die ware stand van sake. En daarom moes 'n groot estetikus soos Volkelt, hoewel hy ook maar net vier hoofnorme laat geld, selfs vanuit sy immanensie-standpunt halt roep: „Man treibt, so scheint es mir, Götz en dients mit der Kunst wenn man sie aus dem Zusammenhang mit dem Guten, mit den Kulturwerten überhaupt, reisst und nicht dulden will, dass die Massstăbe anderer Kulturwerte in ihr zur Anerkennung kommen." (System der Ästhetik, Vorwort bl. VI). En wanneer 'n digter van formaat soos Grillparzer van die waarheid in sy 
kuns getuig met die woorde: „Aber ich fühle, was ich sagte," en dit dan alles soos uit die samehang blyk, op sy gevoel laat aankom, dan mag dit prakties wel waar wees, maar geensins teoreties nie. Want hoeseer ook aanvoeling en invoeling magtig voortstuwende faktore by die skepping is, die verstandelike, om maar een te noem, die denkende handeling, is eweseer betrokke, nie in suiwer logies-analiserende funksie meer nie, maar meewerksaam in die stroom van aanskouinge en gevoelstuwinge, in onderworpenheid aan die leidende beginsel, die skone harmonie.

Die ware van die kunswerk is, ten eerste, gegee in die feitelikheid van die situasie met uitsluiting van dinge wat nie pas nie (anachronisme). Maar in die historiese roman kan verhoudinge na welgevalle verander word, soos dikwels die geval is. In elke goed gekonsipieerde roman is die karakters simbole. Daarom moet die beoordelaar versigtig wees op stuk van natuurlikheid en waarskynlikheid, moet die bedoeling van die outeur begryp. Feitelikheid en voorstellingsvorm vloei hier inmekaar. En wat as onekonomiese gebruik van woorde aangesien wil word, kan noodwendigheid wees, wat as emosionele drang na versadiging strewe.

Die ware sal hom openbaar in gedagte, spraak en gebaar, maar altyd sal die situasie 'n openbaring wees van die leidende idee wat die situasie dra op die bedoelde peil van verbeelding. 'n Mens het dikwels gehoor van karakters wat anders sou praat as in die werklikheid. My arme ou Hans moes dit baie ontgelde-miskien nog in die klaskameromdat hy soms anders praat as verwag word. Dat hy soms anders praat, is waar; dat hy dit daarom moes ontgelde, was onnodig. Want as die beskuldiging juis was, dan moes die helfte of meer van die wêreld se letterkunde oorgeskrywe word.

Laat my net een voorbeeld neem uit Shakespeare soos hy tallose bied.

Die plan tot vermoording van Banquo is op die punt om uitgevoer te word. Macbeth se siel is in die greep van duistere magte en voorstellinge en gewaarwordinge wat die naderende moordnag by hom opwelk.

Dan sê hy vir Lady Macbeth:

„......ere the bat hath flown

his cloistered flight; ere, to black Hecate's summons, the shard-borne beetle with his drowsy hums hath rung nights yawning peal, there shall be done a deed of dreadful note." 
Dit is die woorde van die outeur wat hier in gestileerde vorm uitdrukking gee aan wat in Macbeth se siel as gewaarwording of voorstelling woel, hoewel 'n mens amper mag twyfel of laasgenoemde van die Griekse Hekate sou geweet het. Maar dit daar gelaat. Terwyl dit gewoonlik gebeur in objektiverende woordkuns, is daar egter een voorwaarde aan verbonde, wat die egtheid van die digterlike segging waarborg, nl. die beelding moet gedra word deur voorstellinge wat onteenseglik binne die ervaringswêreldjie van die karakter lê. So objektiveer die outeur die waarheid van die karakter.

Maar waarheen sou die moderne, beeldende, abstraktistiese kuns lei? Of ook die losgelatenheid van die eksistensialisme, tereg genoem die non-eksistensie-filosofie, wat alle norm verwerp en in die woordkuns soos o.a. Sartre in sy Les jeux sont faits 'n gefantaseerde hiernamaals stel, wat in alles met die hierdeuskantse werklikheid ooreenstem: dieselfde vervelende rondslentery in dieselfde strate en parke en kafees, met die enigste onderskeid dat die afgestorwe figure skaduwees is, onsigbaar, sinloos en doelloos, net so sinloos en absurd soos die outeur self hierdie wêreld sien? Sulke fantasterye, hoe vernuftig ook, lei in die leë in-negativisties! Is 'n tendens tot leegheid nie ook al in SuidAfrika bespeurbaar nie?

\section{WAARAGTIGHEID}

Dit is as subjektiewe houding te vat, eienskap van die outeur en eis by alle kunswerksaamheid. Terwyl alle normatiewe funksies van die persoonlikheid vanself betrokke is in die geringste werksaamheid, is geloof en moraal, hoe dié ook al mag wees, van deurslaggewende betekenis by alle kunsskepping. Plagiaat pleeg deur gedagte en selfs woorde van 'n ander bewus oor te neem en uit te gee as van eie maak, sou elke reggeaarde kunstenaar afskrik. Onbewuste beïnloeding egter is vry van morele skuld. En dit is juis hier waar die beoordeling dit so moeilik vind om die regte perspektief te win en waar veel geharrewar in die letterkundige geskiedenis ontstaan het.

'n Ander delikate gebied word gegee deur die moderne manier, veral in liriese werk, om direkte konfrontasie met God of Christus te soek. Waar opregte sieleworsteling voelbaar word, is dit toelaatbaar. Maar op 'n keer kan 'n mens die indruk kry dat hier nie bloed uit die siel getap word nie, maar dat eerder 'n pose van verbeelding aan die orde is. In hierdie verband gryp ek terug na die woorde van Beversluis jare gelede in Elckerlijc: 
„En indien dan in de laatste jaren zooveel gepraat en geschreven wordt over samenbinding, eenheid, vernieuwing en naderende veranderingen, dan is deze slechts denkbaar, indien deze verandering zich in het hart des dichters voltrekt en het wordt omgewenteld en gewekt, ja gerevolteerd in Christus. Alle andere vernieuwingen zijn literaire vervormingen en modulaties om een zinnelijk thema: slechts het innerlijk réveil kan den kunstenaar verlossen uit een aardsch paradijs, dat hij zich nu droomt als een verlossing, maar dat hem verschrikt en nog meer vereenzaamt. De kunstdroom is een labyrinth zonder rustpunt . ..."

Wat is 'n toekoms vir die kuns in Suid-Afrika? Wat die volk nodig het en wat uitgaan as wekwoord aan die adres van jonger literêre en andersoortige kunstenaars, is ' $n$ vernieude hart wat buite-om alle eiegemaakte formuletjies of aangeleerde wysheid van 'n -isme-skool, sal aandryf in die gelouterde vryheid wat die kunstenaar se reg is, om sonder juis te opereer met heilige name, die kunsbeelding op te voer uit groewe en gragte, soekende om in die bewussyn van die Transendente vrugbaar te wees, sodat die geluid wat ons laat hoor, van waaragtig Christelike aard mag wees.

Weg dan met moderniteite wat wil meetel in die koor van 'n ontwortelde wêreld! Laat die stem van ons kuns verkondig, onbeskroomd, ons andersheid wat opkom uit die grond van onkreukbare geslagte, die stem van andersheid ons blankedom waardig, die stem wat vernuwing bring in 'n wêreld sonder hoop, ou waarhede van Christelike integriteit met 'n eie Afrikaanse inhoud.

Dit is ons roeping.

D. F. MALHERBE. 